\title{
TRADUÇÃo DE TEXTOS BÍBLICOS PARA A LINGUAGEM POPULAR: A EXPERIÊNCIA DO CENTRO BÍBLICO DE BELO HORIZONTE
}

\author{
Translation of Biblical Texts into Popular Language: the Belo Horizonte Biblical \\ Center Experience
}

Antônio Geraldo Cantarela *

RESUMO: Este artigo aborda algumas questões relacionadas à tradução de textos bíblicos para a linguagem popular. Tem como pano de fundo a experiência de leitura da Bíblia em Círculos Bíblicos e Comunidades Eclesiais de Base, no Brasil, nos anos 80 do século XX. Remete, em linhas gerais, à experiência de produção de subsídios bíblicos por uma equipe conhecida então como Centro Bíblico de Belo Horizonte. Objetiva-se aqui destacar, de modo particular, algumas preocupações e alguns pressupostos levados em conta por aquela equipe na tradução dos textos bíblicos, bem como apresentar, com pequenos comentários, alguns resultados do trabalho de tradução. Este texto foi construído metodologicamente como memorial crítico daquela experiência pastoral, respaldado na leitura de subsídios então publicados. Além de considerações gerais sobre o trabalho de tradução popular da Bíblia, o ensaio traz a tradução de excertos de algumas passagens da Bíblia, inclusive nos formatos de salmo alfabético, quadra e cordel.

PALAVRAS-CHAVE: Tradução da Bíblia. Linguagem popular. Círculos Bíblicos. Centro Bíblico.

ABSTRACT: This article addresses some issues related to translating biblical texts into popular language: the experience of reading the Bible in Bible Circles and Base Ecclesial Communities (CEBS) in Brazil in the 1980s. In general, the text refers to the experience of producing biblical subsidies performed by a team known at

* Pontifícia Universidade Católica de Minas Gerais, Belo Horizonte, Minas Gerais, Brasil. 
the time as the Biblical Center of Belo Horizonte. The purpose of this article is to highlight, in particular, some concerns and assumptions taken into account by that team in the task of translating the biblical texts, as well as briefly presenting some results of the translation work. This text was elaborated methodologically as a critical memorial of the pastoral experience of that time. In addition to general considerations on popular Bible translation work, the article also provides translations of excerpts from some Bible passages, including the formats of the alphabetical psalm, quadra, and cordel.

KEYWORDS: Bible Translation. Popular Language. Bible Circles. Biblical Center.

\section{Introdução}

$\mathrm{D}$ esde meados do século XIX, quando plantadas em terras brasileiras, as igrejas protestantes utilizaram, em geral, a tradução da Bíblia em português feita por João Ferreira de Almeida, impressa pela primeira vez em volume único nos idos de 1819. A tradução de Almeida, com suas posteriores revisões e atualizações, constituiu sem dúvida importante marco para a disseminação da Bíblia em português. Mais de cem anos depois, no âmbito católico, encontraremos, aqui e alhures, a tradução portuguesa da Vulgata, por Matos Soares (1932), a da editora Ave Maria (1957), a dos Beneditinos (1959) e a dos Capuchinos (1968). Ainda que existissem estas diversas edições católicas da Bíblia em português, o que comumente se encontrava nos lares católicos, até os anos 60 do século XX, era alguma História Sagrada do Antigo e do Novo Testamento, oriunda de Portugal ou de alguma editora brasileira, como a de Bruno Heuser.

No ambiente católico, no Brasil, na esteira do aggiornamento proposto pelo Concílio Vaticano II, particularmente com a promulgação da Dei Verbum, os anos setenta e oitenta conheceram significativos avanços na pastoral bíblica. Editoras católicas investiram maciçamente na popularização da Bíblia. De sua parte, a Conferência Nacional dos Bispos do Brasil (CNBB), dioceses e paróquias promoveram com especial ênfase as campanhas do "Mês da Bíblia" e os cursos de formação de lideranças comunitárias. Grupos de reflexão bíblica, conhecidos como "Círculos Bíblicos", multiplicaram-se às centenas. Centros de estudos bíblicos, dentre os quais se pode destacar o trabalho do CEBI (Centro de Estudos Ecumênicos Bíblicos), fundado por Carlos Mesters, espalharam-se pelo país, assessorando cursos bíblicos e respondendo às demandas gestadas pela descoberta e pela leitura da Bíblia.

Este ensaio pretende destacar a atividade do grupo de assessoria bíblica conhecido como Centro Bíblico de Belo Horizonte. As raízes do grupo podem ser encontradas no final dos anos 60 e início dos anos 70, no serviço de assessoria - oferecido por Carlos Mesters - aos primeiros Círculos 
Bíblicos de que se tem notícia na Arquidiocese de Belo Horizonte. Da grande efervescência pastoral em torno da Bíblia brotou a necessidade de produção de roteiros escritos, em vista de consolidar o "método" de ler a Bíblia configurado nos Círculos Bíblicos.

Em razão da grande demanda por subsídios que ajudassem na leitura popular da Bíblia, a equipe do Centro Bíblico de Belo Horizonte, com o suporte técnico de Edições Paulinas, propôs-se o desafio de produzir roteiros bíblicos que tivessem alcance nacional. Nasceu assim, em 1978, o semanário Bíblia - Deus caminhando com a Gente, mais conhecido como Bíblia-Gente. A equipe era formada, então, por Alberto Antoniazzi (in memoriam), padre da Arquidiocese de Belo Horizonte, Wolfgang Gruen, padre salesiano, Inês Broshuis, do Instituto Secular Unitas, Antonio Geraldo Cantarela, leigo, e Maria Pia Di Dio, paulina, substituída depois por Ir. Rosana Pulga. Este grupo, permanente, contou com a colaboração esparsa de outros integrantes.

A equipe reuniu-se semanalmente de 1978 a 1990. Além do semanário Bíblia-Gente, produziu inúmeros roteiros de Círculos Bíblicos para a Campanha da Fraternidade e diversos subsídios para o Mês da Bíblia. No processo de elaboração desses materiais de apoio à leitura da Bíblia, o grupo teve em especial apreço a questão da linguagem. A intenção era oferecer um texto acessível, que permitisse aos participantes dos Círculos Bíblicos realizar suas reuniões sem depender da presença de agentes de pastoral especializados ou de leitores exímios. No bojo dessa preocupação, foram traduzidos inúmeros textos bíblicos.

Este ensaio relê aquela experiência pastoral de traduzir textos bíblicos para a linguagem popular. Configura como que um memorial crítico daquele serviço pastoral, apresentado aqui em dois tópicos: i) Considerações gerais sobre a experiência de tradução de textos bíblicos para uma linguagem popular, onde se enumeram alguns pressupostos de viés teológico subjacentes ao trabalho de tradução popular da Bíblia e onde se destacam alguns aspectos da proposta de tradução popular, com seus fundamentos; ii) Tradução de algumas passagens bíblicas, de diferentes gêneros textuais, escolhidas dentre publicações daqueles anos, com pequenos comentários construídos pelo olhar de hoje.

\section{Considerações sobre uma experiência de tradução de textos bíblicos para a linguagem popular}

Traduzir um livro da Bíblia não se iguala a realizar qualquer outro trabalho de tradução. Para além da tarefa técnica de verter o léxico, a estrutura gramatical e o universo cultural das línguas bíblicas para um idioma moderno, a tradução do texto bíblico implica um pressuposto fundamental: trata-se 
da lida com um texto canônico, um texto que de algum modo se diferencia de outros por seu caráter de santidade e normatividade. A tarefa se torna ainda mais exigente quando se pensa em tradução popular da Bíblia. A primeira pergunta que se impõe diz respeito ao adjetivo "popular". O que significa "popular"? Não vamos entrar na turbulência desse debate. Por mais polissêmico que seja, usa-se aqui o termo "popular" para referir-se ao "leitor comum", aquele que não dispõe das ferramentas dos exegetas e dos especialistas. Assim, além das implicações teológicas subjacentes à tarefa de traduzir o texto sagrado, há ainda que fazer perguntas sobre o leitor atual e seu mundo, o "leitor comum", particularmente aquele "de pouca leitura", que não dispõe de traquejo suficiente que lhe permita realizar uma leitura um pouco mais avançada. Algumas dessas questões serão tratadas a seguir.

\subsection{Pressupostos gerais de viés teológico}

Um dos princípios fundamentais que devem reger a tarefa de tradução da Bíblia para a linguagem popular correlaciona-se à compreensão que o povo tem da Bíblia. Trata-se de um livro santo, uma escritura que pertence ao âmbito do sagrado. Tal condição não decorre da mera separação de alguns textos do mundo cotidiano para consagrá-los ao nível das sacralidades, mas de alguma vinculação misteriosa com a santidade de Deus (ARTOLA, 2005, p. 43). Essa condição misteriosa que faz da Bíblia uma escritura santa não a desvincula, entretanto, da história. Pelo contrário: daí nasce seu caráter normativo para a vida cotidiana da comunidade. Mais ainda: o caráter normativo das Escrituras não diz respeito apenas à vida da fé expressa nas doutrinas, nos ritos e no culto. Trata-se, bem mais, da disposição ativa por tomar as Escrituras como orientação e medida para a vida social em sua totalidade. Por tudo isso, o texto bíblico é "imexível". Assim, em suas traduções, a equipe do Centro Bíblico de Belo Horizonte procurou evitar o uso de palavras e expressões por demais corriqueiras ou consideradas "chulas", que pudessem criar tropeços ou solapar a concepção de santidade de que se reveste a Bíblia.

Intimamente relacionado ao princípio da santidade das Escrituras, destaca-se o valor sacramental da Bíblia enquanto livro. Ainda que o trabalho da equipe culminasse na publicação de folhetos e livretos de apoio à leitura da Bíblia, sempre se incentivou a utilização do livro-Bíblia, por sua densidade simbólica. A Bíblia não é um livro qualquer. Ocupa lugar proeminente não somente na igreja ou em outro local onde a comunidade se reúne para rezar, mas também na sala de muitas casas. Não raro, é o único livro que muitas famílias possuem. Ainda que a imagem de alguém com "a Bíblia debaixo do braço" tenha sido usada para caricaturar o evangélico, o "crente", o costume de levar a Bíblia para as reuniões do Círculo Bíblico tornou-se comum também no meio católico. 
Outro fundamento que sustentou o esforço da equipe do Centro Bíblico de traduzir textos bíblicos para uma linguagem mais simples e popular apoiava-se no princípio teológico da "opção preferencial pelos pobres", que marcou a teologia latino-americana naqueles anos. Em correlação com a "santidade do livro", falava-se também da "santidade do povo". Em relação ao trabalho de tradução, este princípio obrigou a equipe, a todo o tempo, a não confundir simplicidade com superficialidade. As pessoas que frequentavam os Círculos Bíblicos relatavam vivências de grande profundidade; e faziam reflexões igualmente densas a respeito de suas experiências. Seus relatos, entretanto, eram tecidos com extrema simplicidade. Animada por tal perspectiva, a equipe apoiou-se, de um lado, no pressuposto de que havia uma demanda por subsídios bíblicos que as pessoas simples do povo dessem conta de ler e compreender. De outro lado, acreditou que, ao fim e ao cabo, se os seus folhetos e livretos não alcançassem plenamente o objetivo para o qual eram feitos, a experiência de vida do povo, com sua sabedoria, com sua fé, bastaria para suprir as lacunas da assessoria pastoral. Diante disso, a equipe sugeria que, de preferência, a pessoa lesse a Bíblia junto com outros.

\subsection{A tradução popular da Bíblia: a proposta e seus desafios}

Em linha de princípio, qualquer texto foi escrito para ser lido e compreendido - mesmo quando traduzido de uma cultura a outra. No caso da Bíblia, pode-se imaginar que textos do gênero narrativo, como as sagas, lendas e contos, textos jurídicos, hinos e salmos, textos sapienciais foram, em seu conjunto, lidos e acolhidos pelos seus primeiros destinatários sem maiores problemas para sua compreensão. Vale observar que textos desses gêneros constituem a maior parte dos escritos bíblicos, o que permite inferir que a maior parte da Bíblia não deve ter sido, então, de difícil compreensão.

Isto não significa dizer que aqueles leitores do passado leram e ouviram os textos bíblicos sem esbarrar em alguma dificuldade. Bastaria lembrar a cena do livro de Atos dos Apóstolos (Atos 8,26-40), do encontro entre Filipe e o eunuco etíope da rainha Candace. O etíope estava a ler uma passagem do profeta Isaías. Interrogado por Filipe, se entendia o que estava lendo, responde o eunuco: “Como eu poderia entender se alguém não me explicar?" Não faltam exemplos de dificuldades que leitores do passado experimentaram na recepção dos textos bíblicos.

Cerca de dois mil anos depois de definido o cânon bíblico, as dificuldades de leitura da Bíblia obviamente aumentaram. A primeira dificuldade advém do fato da distância cultural que existe entre nós e o mundo da Bíblia (OXTOBY, 1995). Referindo-nos à dimensão cultural que subjaz à tarefa da tradução, parafraseamos o especialista e professor de tradução Jean-René Ladmiral (1980, passim p. 46-47): “A língua materna é muito mais do que um instrumento de comunicação que veicula informações". Na tarefa de 
traduzir, "o que está em causa não é, portanto, uma competência de ordem estritamente linguística".

Certamente, colocamo-nos na esteira de uma tradição cultural que tem na Bíblia uma de suas principais referências literárias e normativas. Desse ângulo, os textos bíblicos não foram escritos menos a nós que a seus leitores do passado. E, em teoria, seriam por isso compreendidos. Entretanto, uma observação rasa do que muitas vezes acontece no ato da leitura da Bíblia bastaria para fornecer uma tese contrária: nem tudo de um texto é compreendido; ou, no extremo, o texto inteiro não é compreendido. Na lida com os Círculos Bíblicos, a equipe do Centro Bíblico encontrava outra dificuldade: a pouca escolaridade da maioria das pessoas que frequentavam as reuniões. Como traduzir de uma cultura a outra? Como lidar com o limite da "pouca leitura"? Como, enfim, traduzir para uma linguagem popular? Tendo em conta tais perguntas, destacam-se a seguir alguns caminhos trilhados por aquela equipe em busca de oferecer uma tradução popular dos textos bíblicos.

a) Escrever com frases curtas, em ordem direta, com base em outras traduções

Tomando como base a tradução da Ave Maria e, a partir de 1981, a da Bíblia de Jerusalém, a tradução era feita obedecendo a um critério literário básico: reescrever o texto bíblico com frases curtas, de não mais de três linhas, possivelmente em ordem direta - sujeito e predicado. Do ponto de vista de estilo, nem sempre nascia daí um texto bonito. Entretanto, a experiência demonstrou ser uma escolha que melhorava sensivelmente a capacidade de leitura dos participantes de Círculos Bíblicos.

Além de consultar também outras edições em português, como Matos Soares e Ferreira de Almeida, quando surgiam dúvidas quanto à melhor opção de palavra ou expressão, a equipe buscava socorro ainda em algumas edições estrangeiras modernas, como a Nueva Biblia Española traduzida por Alonso Schökel (1976), ou La Nueva Biblia Latinoamerica (1974) ou ainda La Bibbia, da Civiltà Cattolica (1974).

Para os textos do Novo Testamento, a equipe contava finalmente com os conhecimentos de grego de Wolfgang Gruen, membro da equipe, que de há muito lecionava grego bíblico. Para o Antigo Testamento, como não havia na equipe alguém que lidasse com o texto hebraico, consultava-se quando preciso, algum dicionário. Tais consultas ajudaram a dirimir dúvidas ocasionais.

b) Traduzir o sentido da palavra ou da expressão sem massacrar o estilo Um dos problemas mais característicos da tradução - de qualquer tradução - diz respeito à dificuldade de escolher entre a literalidade da palavra, com 
sua referência primeira, e o seu sentido mais amplo, mais denso, simbólico. Certamente, tal problema não ocorre a todo momento. Mas, quando ocorre, como por exemplo traduzir o termo hebraico nêfesh? Vida? Alma? O termo ocorre mais de 750 vezes no texto hebraico, num leque semântico muito variado. Traduzi-lo sempre por "alma", como já se fez, não parece uma boa opção. Da mesma forma, como traduzir leb ou lebab? Também este termo, que aparece cerca de 850 nos originais hebraicos, encontra-se em variado leque semântico. Literalmente, esta palavra hebraica poderia ser traduzida por "coração". Mas o que significa metaforicamente "coração" na cultura judaica antiga? Os especialistas sabem que se trata do órgão da razão e não do afeto, como para nossa cultura. Para a Bíblia, o órgão do amor cuidadoso são os "rins". Citamos os exemplos apenas para dizer que, em nossas traduções, quando aconteciam impasses dessa natureza, recorríamos a obras de antropologia bíblica, como a de Hans Walter Wolff (1975) que, traduzida na época para o português, por Loyola, foi de grande ajuda em nosso trabalho.

Em pequeno texto dedicado ao problema da relação entre sentido e estilo, nos processos de tradução, o linguista e tradutor Charles R. Taber nos oferece esta definição: "A tradução consiste em reproduzir na língua receptora a mensagem da língua de origem, por meio do equivalente mais próximo e mais natural, primeiramente no que diz respeito ao sentido, em seguida no que concerne o estilo" (TABER, 1980, p. 88). A definição, retomada da obra mais volumosa, em coautoria com o linguista e especialista em tradução da Bíblia Eugene Albert Nida (NIDA; TABER, 1986), apoia-se em alguns postulados. O pressuposto é de que "o sentido é essencialmente idêntico à estrutura semântica", a estrutura profunda, o conteúdo conceptual e afetivo que o texto carrega. O vocabulário, a morfologia e a sintaxe, ainda que estabeleçam estreita correlação com a estrutura semântica, configuram a estrutura de superfície. Constituem mediações cuja escolha, em sua diversidade, caracteriza o estilo. Conforme Taber, a tradução ideal procurará traduzir não apenas o conteúdo, mas também os traços formais, de estilo, do texto original (TABER, 1980, p. 90-91). Em instigante capítulo sobre a natureza da tradução, Nida e Taber (1986, p. 29-54) falam da boa tradução em termos de um sistema de prioridades: da conformidade contextual sobre a verbal, da equivalência dinâmica sobre a correspondência formal, da linguagem falada sobre a escrita, das necessidades dos receptores sobre formas literariamente mais prestigiadas.

Apoiados sobre pressupostos dessa natureza, a equipe do Centro Bíblico de Belo Horizonte optou então por oferecer uma tradução popular dos textos bíblicos que levasse em conta também o estilo dos autores bíblicos. Em relação a isso, a atenção à experiência dos evangélicos ofereceu uma dupla contribuição. De um lado, a equipe rejeitou - como muitas igrejas evangélicas - o estilo da tradução do Novo Testamento de A Bíblia na Linguagem de Hoje (1975), publicada pela Sociedade Bíblica do Brasil. A 
tradução, a propósito muito usada no ambiente católico, pendia muitas vezes para uma espécie de paráfrase do texto bíblico. Certos termos paulinos, por exemplo, eram ao mesmo tempo traduzidos e explicados. Com isso, não raro, o estilo do autor bíblico acabava prejudicado pelas explicações. De outro lado, as igrejas evangélicas ensinavam que mesmo um texto erudito, com um português algumas vezes arcaico, como é o caso da tradução do Ferreira de Almeida, pode se tornar acessível, na medida em que vai sendo reconhecido por sucessivas leituras, na medida em que vai ficando "no ouvido" do leitor, sabido quase de cor.

c) Ponto nevrálgico: apenas traduzir o texto bíblico ou oferecer um curso sobre ele?

Um ponto que por diversas vezes pautou as discussões da equipe do Centro Bíblico de Belo Horizonte dizia respeito ao tipo de publicação mais adequado às necessidades dos participantes dos Círculos Bíblicos. O que oferecer? Uma boa tradução do texto bíblico? Ou a tradução acompanhada de um curso sobre o texto? A equipe acabou por escolher os dois formatos.

Ao apresentar o relatório de pesquisa realizada em 1982, com o objetivo de avaliar a recepção oral e escrita de diferentes traduções da Bíblia, por parte do povo, Alberto Antoniazzi, já no início de seu texto, coloca a questão: "O que o povo entende, lendo a Bíblia?" E oferece uma resposta que nos obriga a pensar nos critérios de validação da leitura da Bíblia feita pelo leitor comum, aquele que não dispõe das mesmas ferramentas do especialista e do exegeta profissional. Responde Antoniazzi (1982, p. 15): "A pergunta é ampla demais, para ser objeto de uma pesquisa. E se poderia discutir se o modo de entender do exegeta ou especialista é melhor que o do povo."

Alguns subsídios - como A história de José (GRUEN; CANTARELA, 1980), feito para o Mês da Bíblia de 1980, e a Carta aberta de Tiago (GRUEN; CANTARELA, 1981), para o Mês da Bíblia de 1981 - foram pensados num formato muito simples: uma introdução ao escrito bíblico, o texto bíblico propriamente dito, com algumas poucas notas explicativas, e uma seção com perguntas e questionamentos sobre o texto. A proposta era que a tradução, o mais fiel e popular possível, e os poucos subsídios que a acompanhavam, fossem suficientes para alimentar a reflexão e a ação dos grupos de Círculos Bíblicos e comunidades que tivessem acesso ao material. A equipe sugeria expressamente que os leitores evitassem escarafunchar o texto bíblico, à busca de curiosidades, ou se preocupassem com questões técnicas como autoria, data de redação e primeiros destinatários. Pouco interessavam as informações oferecidas pela crítica histórica. Tratava-se, ao fim e ao cabo, de evitar ler a Bíblia como obra do passado.

À medida que os participantes dos Círculos Bíblicos criavam mais familiaridade com a Bíblia, surgiram também perguntas acerca do mundo da 
Bíblia, da história do povo que a forjou, dos costumes daquele tempo, da situação histórica em que Jesus viveu. Frente à demanda, justificou-se a oferta de subsídios que, a um só tempo, trouxessem informações sobre o Israel dos tempos bíblicos, sem, contudo, perder de vista o interesse atual daquelas narrativas. Nessa direção caminhou o semanário Bíblia-Gente, desde seu nascimento, em 1978, até, pelo menos, o ano de 1988, período em que sua redação esteve sob a responsabilidade do Centro Bíblico de Belo Horizonte. Também o subsídio Rute, uma história da Bíblia, feito para o Mês da Bíblia de 1985, ofereceu uma tradução popular do texto bíblico, feita por Antonio G. Cantarela, com comentários bíblicos tecidos por Carlos Mesters. Ainda que a escolha por ler o texto bíblico sem muitos comentários tenha sido sobrepujada pelo formato de cursos, estes não se detinham na Bíblia enquanto história do passado; provocavam o leitor atual e apostavam em sua capacidade de leitura e na sua autonomia em aprender pela experiência de vida e pela pertença a uma comunidade cristã.

d) Fatores externos ao texto bíblico que podem facilitar sua leitura

Além dos desafios intrínsecos à tarefa de traduzir o texto bíblico para a linguagem popular, existem também certos fatores externos ao texto que podem dificultar ou facilitar sua leitura. Uma enquete realizada em 1977 na região dos bairros Dom Cabral e João Pinheiro, em Belo Horizonte, perguntava aos participantes dos Círculos Bíblicos acerca de suas dificuldades na leitura da Bíblia. Para surpresa dos pesquisadores, apareceram com grande frequência respostas do tipo "a luz do bairro é fraca" e "a letra da Bíblia é muito pequena".

Frente a tais dificuldades, além da opção por frases curtas e em ordem direta - conforme já comentamos acima - o Centro Bíblico de Belo Horizonte procurou oferecer subsídios com letra maior que aquelas comumente encontradas nas edições da Bíblia. Preocupou-se também com a diagramação dos textos, de modo que as frases não fossem necessariamente até o final de uma linha, mas mudassem de linha quando as pausas construídas pela pontuação o exigissem. Na busca por uma boa diagramação que facilitasse a leitura, foi evitada a hifenização de palavras ao fim da linha.

Além dos aspectos relativos à apresentação gráfica dos textos, durante a fase inicial de seu trabalho com tradução de textos bíblicos, a equipe testou suas traduções com leitores participantes dos Círculos Bíblicos. Quando o leitor comum "engasgava" no ato da leitura, quase sempre era sinal de que havia alguma coisa a ser melhorada naquele ponto.

A experiência acabou por ensinar que uma tradução popular da Bíblia pode alcançar resultados satisfatórios, do ponto de vista de sua recepção, quando se procura a equivalência de sentido e de estilo, em relação ao texto original, mas também quando se responde às necessidades do leitor atual relativamente a aspectos gráficos com os quais o texto se apresenta. 
Outro aspecto externo ao texto bíblico, mas de grande importância por sua estreita relação com a tradução e a leitura popular da Bíblia, deve ser mencionado. Quase sempre aqueles subsídios foram produzidos em regime de "campanha", o que equivale a dizer que tiveram enorme apoio de dioceses e paróquias, no sentido de adquirir e repassar o material aos grupos de Círculos Bíblicos. A produção em larga escala daqueles subsídios fez com que seu custo se tornasse relativamente baixo. Do ponto de vista gráfico, a opção por produzir os livrinhos em papel jornal, no formato de bolso $(18 \times 13 \mathrm{~cm})$, com número de páginas múltiplo de 16 o que facilitava o sistema de impressão, de dobradura e de grampeação do material pelas máquinas de então - representou fator primordial no barateamento dos custos dos livrinhos.

\section{Textos bíblicos em linguagem popular}

Durante os cerca de onze anos em que se reuniu para assessorar a pastoral bíblica, a equipe do Centro Bíblico de Belo Horizonte produziu em torno de mil e trezentos roteiros de Círculos Bíblicos, publicados no semanário Bíblia-Gente. Cada folheto do semanário trazia, normalmente, dois roteiros: um dedicado ao texto bíblico da liturgia dominical e outro no formato de curso seriado, sobre temas diversos. Assim, de meados de 1978 ao final de 1980, foi oferecido um curso de introdução ao Antigo Testamento, com 108 roteiros de Círculos Bíblicos. Em 1981, foram redigidos 47 Círculos Bíblicos sobre os escritos paulinos. Em 1982, a equipe focou o texto de Marcos com pouco mais de 40 roteiros de reuniões. Em 1983, a temática escolhida teve em vista a formação dos grupos bíblicos. Em 1984, a equipe refletiu sobre os sacramentos; em 1985, sobre os mandamentos; em 1986, o tema escolhido foi Jesus de Nazaré. Outros temas ocuparam o-que-fazer da equipe.

Além desses roteiros de reuniões bíblicas, o Centro Bíblico de Belo Horizonte redigiu os Círculos Bíblicos de algumas Campanhas da Fraternidade e de vários Meses da Bíblia. Destacam-se, dentre outros, os roteiros de reflexão sobre Gênesis, para o Mês da Bíblia de 1980; sobre as parábolas de Jesus, para o ano de 1982; sobre o livro do Apocalipse, para o Mês da Bíblia de 1983; sobre o livro de Atos dos Apóstolos, para o ano de 1984; sobre o livro de Rute, para 1985. Além dos roteiros para Círculos Bíblicos, a equipe produziu também alguns livrinhos para as campanhas do Mês da Bíblia. Colaborou ainda com o CEBI, de Carlos Mesters, na elaboração de subsídios sobre o livro do Apocalipse, para o Mês da Bíblia de 1983, e sobre o livro de Rute, para o ano de 1985.

Desse volumoso material - cerca de 2 mil laudas de texto - este ensaio selecionou alguns textos bíblicos com o objetivo de mostrar, de forma ilustrativa, resultados concretos do esforço por oferecer a Bíblia numa 
tradução que se pretendeu popular. Foram escolhidas passagens bíblicas de gêneros textuais diversos (narrativas, oráculos proféticos, salmos, poesia sapiencial), em vista de apontar possibilidades e limites diversos da tarefa de traduzir. A classificação dos textos, expressa abaixo de forma genérica, serve apenas para reunir em cada subtópico gêneros textuais diversos, mas com alguma característica em comum. Além da tradução popular, são tecidos alguns poucos comentários sobre questões a ela afeitas.

Aos leitores deste ensaio que tiverem especial interesse na problemática da tradução popular da Bíblia, sugere-se que comparem a tradução aqui apresentada com alguma outra de sua preferência. E façam sua avaliação. Sem mais, vamos aos textos bíblicos.

\subsection{Tradução de textos bíblicos do gênero narrativo}

Os textos do gênero narrativo constituem a maior parcela da Bíblia. Configuram as narrativas sobre os Patriarcas, praticamente todos os Livros Históricos, os contos bíblicos (Jonas, Rute, Tobias, Ester, Judite), muitos livros proféticos, os Evangelhos, o livro de Atos dos Apóstolos, os apocalipses canônicos (Daniel e Apocalipse de João). Certamente, esses textos trazem inúmeros traços que os tornam muito diferentes entre si. Entretanto, portam em comum a presença de um narrador.

A escolha de algumas passagens bíblicas do gênero narrativo tem o objetivo de destacar dois aspectos da tradução popular: um referente à estrutura das frases e outro referente à questão do uso da linguagem excessivamente corriqueira.

Em relação à estrutura das frases, parece que os textos do gênero narrativo se apresentam como os mais fáceis de traduzir para a linguagem popular. Sem desmerecer aspectos centrais da tradução, como aqueles relacionados ao imaginário cultural do passado, a experiência da equipe do Centro Bíblico permite afirmar que uma solução relativamente simples para a tradução desses textos está em apresentá-los com frases bem curtas.

Outro aspecto, este mais complicado, diz respeito ao risco de o leitor criar uma imagem negativa da tradução, pelo fato de ela se apresentar numa linguagem excessivamente corriqueira, quiçá desrespeitosa para com o caráter de santidade que marca o imaginário sobre a Bíblia. Em Gênesis 37, por exemplo, o autor bíblico apresenta José como um jovem sonhador. Entretanto, chamá-lo de Zé-dos-sonhos, como faz a tradução abaixo, ainda que na perspectiva irônica dos irmãos, por mais que atenda a uma equivalência de sentido em relação ao texto original, pode parecer uma mácula contra o texto bíblico.

Outra questão, também relativa ao uso da linguagem informal e cotidiana, tem a ver com o uso de gírias e expressões de época, na tradução popu- 
lar. Além da ideia de desrespeito para com a Bíblia, já apontado acima, elas correm o risco de obsolescência. Assim, muitos leitores de hoje terão alguma dificuldade em entender o versículo que afirma: "a mulher do patrão ficou gamada por José" (Gênesis 39,7). Quem saberá, hoje, o que significa "ficou gamada"? No caso da história de José, a leitura da cena por inteiro pode resolver o problema.

Problema semelhante pode ocorrer na leitura da parábola do patrão-mão-aberta (Marcos 20,1-15). O dono da vinha combina pagar "um barão" por dia. Em 1982, quando foi feita a tradução, a diária de um trabalhar braçal, de serviços gerais, era em torno de mil cruzeiros - valor representado pela cédula que trazia a efígie do Barão do Rio Branco. $\mathrm{O}$ valor de mil cruzeiros ficou popularmente conhecido como "um barão". A tradução perdeu todo o sentido para o leitor de hoje.

Convidamos os leitores a conferir tais aspectos nas passagens abaixo.

a) Excertos da história de José (Gênesis 37,18-22 e 39,7-20)

José foi atrás dos irmãos. Encontrou-os em Dotam.

Os irmãos viram José de longe.

Antes de ele chegar perto, combinaram acabar com o rapaz.

Falaram uns aos outros:

- Lá vem o Zé-dos-sonhos. Vamos acabar com o sujeito?

A gente o joga numa cisterna. Diz que um bicho o comeu.

Aí, vamos ver onde vão parar os sonhos dele.

Rubem ficou só ouvindo.

Queria salvar José das mãos dos irmãos. Falou assim:

- Matar, não!

E continuou:

- Não vamos derramar sangue.

É melhor jogá-lo nessa cisterna, perdida por aqui.

Mas levantar a mão contra ele, não.

Rubem queria mesmo era salvar o irmão para levá-lo de volta a seu pai. (GRUEN; CANTARELA, 1980, p. 16-17).

Depois aconteceu o seguinte: a mulher do patrão ficou gamada por José. Ela disse:

- Venha deitar comigo.

José recusou. Disse à mulher de seu patrão: 
- Olhe! Meu patrão não me pede conta de nada do que acontece na casa. Tudo o que tem, ele deixou em minhas mãos.

Ninguém aqui tem mais autoridade que eu.

Ele não me tem negado nada, fora a senhora, que é a mulher dele.

$\mathrm{Eu}$, cometer um mal tão grande? Pecar contra Deus?

Dia após dia, a mulher tentava José.

Mas ele não dava confiança para dormir com ela. Não admitia intimidades. Certo dia, José entrou na casa para despachar serviços.

Nenhum empregado estava ali dentro. A mulher agarrou José pelo manto e disse:

- Venha deitar comigo.

Ele largou o manto nas mãos dela e escapuliu. Vendo que José tinha largado o manto em suas mãos e fugido, a mulher reuniu os empregados. Contou ao pessoal:

- Vejam só! Meu marido trouxe aqui esse gringo hebreu para abusar da gente.

Não é que ele me perseguiu para deitar comigo? Eu gritei, com toda força.

Quando viu que eu gritei bem alto, ele largou a roupa perto de mim e escapuliu.

Saiu correndo.

A mulher guardou o manto de José até o marido chegar em casa.

Repetiu-lhe a mesma história:

- Ele me perseguiu para abusar de mim, o escravo, aquele hebreu que você trouxe.

Quando eu gritei bem alto, ele largou o manto ao meu lado e saiu correndo.

Quando ouviu as palavras de sua mulher,

"Esse seu escravo fez isso e aquilo", o patrão ficou uma fera.

Meteu José na cadeia. Estavam lá os presos do rei. José ficou na prisão.

(GRUEN; CANTARELA, 1980, p. 21-22).

b) A parábola do patrão-mão-aberta (Marcos 20,1-15)

O Reino de Deus é assim:

Certa manhã, um dono de vinha saiu para a praça.

Foi contratar peão para trabalhar na sua plantação de uva.

Combinou com os operários:

- Um barão por dia! 
Aí, mandou os trabalhadores para a vinha.

Antes do meio-dia, o patrão voltou na praça

e viu muitos homens à toa, sem trabalho. Falou com eles:

- Estão caçando serviço?

Vão lá para a minha plantação de uva. Eu pago bem!

Eles foram.

Logo depois do meio-dia, o patrão foi de novo contratar trabalhadores.

E lá pelas tantas da tarde, a mesma coisa.

E mais uma vez, quando estava quase na hora de terminar o dia,

o patrão voltou à praça.

Encontrou um monte de gente desocupada. Perguntou:

- Por que vocês ficam aí, o dia inteiro sem fazer nada?

Eles responderam:

- Porque ninguém arranjou serviço para a gente.

Aí, o patrão disse:

- Vão também vocês para a vinha.

No fim da tarde, na hora de acertar as contas, o patrão disse ao administrador:

- Chame os homens e pague o dia.

Comece pelos que chegaram por último e pague depois aos primeiros. Aqueles que chegaram no fim da tarde vieram receber.

Cada um ganhou mil cruzeiros.

Quando chegou a vez dos primeiros, aqueles que chegaram de manhã, eles pensaram que iam receber muito mais.

Que nada! Só um barão cada um.

Aí, eles começaram a murmurar contra o patrão. Diziam:

- Esses últimos só trabalharam uma horinha e o senhor pagou a eles igual a nós.

Nós aguentamos o peso de um dia inteiro, debaixo do calor do sol.

O patrão falou com um deles:

- Meu amigo, acha que eu fui injusto com você?

Quanto foi que combinamos? Não foi um barão?

Pois é. Pegue então o que é seu e vá embora.

Quero dar a esses últimos o mesmo tanto que paguei para você.

Será que não tenho o direito de fazer o que eu quero com o que é meu?

Você está com olho-gordo porque eu sou bom?

Depois de contar esta parábola, Jesus ainda comentou: 
- Pode acontecer que os últimos se tornem os primeiros.

E os primeiros fiquem por último.

(CANTARELA, 1982, p. 11-12).

\subsection{Tradução de textos bíblicos do tipo exortativo (oráculos proféticos e outros)}

Apresentamos aqui, sob a denominação de "exortativo", a tradução popular de três excertos de diferentes gêneros textuais da Bíblia: oráculo profético, epístola e apocalipse. Na Bíblia, com grande frequência, esses gêneros textuais aparecem mesclados com outros, principalmente as narrativas. O critério para reuni-los num mesmo bloco, além do tom exortativo que trazem em comum, foi em vista de destacar algumas escolhas adotadas no processo de tradução.

$\mathrm{Na}$ falta dos recursos gráficos de pontuação de que dispomos hoje, as línguas bíblicas fizeram uso de palavras e fórmulas de ligação ou continuidade do texto, como "perguntou", "respondeu", "aconteceu", "depois disso", "e". De nossa parte, ao traduzir o frequente "egéneto" ou "kai" do grego bíblico, por exemplo, optamos por certas fórmulas usuais do meio popular, frequentes na linguagem oral, como "aí" e "então".

De modo mais particular, no caso da passagem de Isaías, abaixo, os termos "protetor" e "protegido", comumente encontrados nas traduções em português, foram traduzidos por "padrinho" e "afilhado", cujo uso irônico permite indicar o alcance político da crítica profética. Foram usadas ainda expressões tipicamente populares como "descer o braço" e "quem pode mesmo", para falar do poder de Deus, em contraposição a "carne-e-osso" de que são feitos os cavalos dos egípcios.

Na tradução de Tiago, em lugar de "epístola", foi escolhida para compor o título a expressão "carta aberta", de uso político muito frequente nos anos 80 do século XX. Na mesma linha, adotou-se o termo "ação" em lugar de "obras", tendo em vista sua relevância trazida pelo método ver-julgar-agir, preconizado pelas campanhas pastorais da Igreja Católica no Brasil.

Na tradução da passagem de Apocalipse, em vez de utilizar simplesmente o termo "anjo", para indicar a liderança da igreja, optou-se por "anjo dirigente", considerando a importância do cargo de dirigente no contexto dos Círculos Bíblicos e das Comunidades Eclesiais de Base.

Outro recurso muito presente nas traduções populares foi o de construir algumas frases como pergunta e não como afirmação. Além de ajudar na quebra de frases longas, funcionava como estímulo à reflexão. 
a) Oráculo de Isaías contra a aliança com o Egito (Isaías 31,1-3)

Ai daqueles que vão pedir socorro no Egito!

Confiam no apoio de sua cavalaria;

nos carros de guerra, porque são numerosos;

põem fé nos soldados, porque são valentes.

Mas não olham para o Santo de Israel;

não se aconselham com o Senhor.

Ora, quem pode mesmo é Deus!

Ele sabe ser terrível;

é um aliado fiel.

Deus desfaz os planos dos agressores

e de todos os que vão atrás deles.

$\mathrm{O}$ egípcio é homem e não deus.

Seus cavalos são carne-e-osso e não espírito.

Deus vai descer o braço:

o "padrinho" vai cambalear;

o "afilhado" cairá;

vão se acabar os dois juntos.

(BÍBLIA-GENTE, v. 2, n. 13, 18/03/1979, p. 2)

b) Tiago: a fé sem obras é morta (Tiago 2,14-18)

Meus irmãos,

Se alguém diz que tem fé, mas não faz nada,

essa fé poderá salvá-lo?

Por exemplo:

Aparece uma irmã ou um irmão que não tem onde cair morto: sem roupa, passando fome.

Aí, um de vocês pega e diz:

- Vá em paz! Deus é grande!

Ele dá o frio conforme a roupa.

Ele dá a fome conforme a panela.

Mas providenciar a comida e a roupa

de que o irmão precisava, nada!

Adianta alguma coisa?

Também a fé é assim:

se não tiver ação, já está morta. 
Há pessoas que ainda insistem.

Com elas você pode argumentar assim:

- Você tem fé, eu tenho ação.

Mostre-me a sua fé sem ação.

Eu the mostrarei a minha fé pela ação.

(GRUEN; CANTARELA, 1981, p. 14-15.

BÍBLIA-GENTE, v. 4, n. 39, 20/09/1981, p. 1-2)

c) Carta à Igreja de Laodiceia (Apocalipse 3,14-19)

O Vivente Ressuscitado deu ordem a João:

- Escreva uma carta ao Anjo dirigente da comunidade de Laodiceia.

Escreva assim:

- Cristo é o Amém de Deus. É o testemunho fiel e verdadeiro.

É o Primeiro; as coisas criadas vêm depois dele. Escute sua palavra. Ele diz:

- Conheço você muito bem: não é frio nem quente.

Quem dera que você fosse frio ou quente! Mas você é morno! Nem frio nem quente. Você já chegou na boca. Estou quase te vomitando. Você diz:

- Sou rico! E agora que sou rico não preciso de mais nada.

Pois então, escute lá:

- Você é um infeliz e não sabe disso. É pobre, cego e nu. Quer um conselho?

Quer mesmo ficar rico? Então compre o meu ouro, ouro puro, derretido no fogo.

Quer se vestir bem? Compre minhas roupas brancas, para cobrir sua sem-vergonhice. Está querendo enxergar? Pois eu tenho o colírio para seus olhos.

Meu sistema é este: repreendo e educo quem eu amo. Dê um jeito! Ande! Anime sua fé! Mude de vida!

(BÍBLIA-GENTE, v. 6, n. 38, 11/09/1983, p. 2).

\subsection{Tradução de salmos e de textos bíblicos do gênero poético sapiencial}

A tradução popular de hinos e salmos não se mostra, quanto ao conteúdo, um grande problema. Em linhas gerais, os temas desse gênero de texto se mostram universais. Falam da vida humana em forma de oração. 
Alternam-se, algumas vezes num mesmo salmo, súplica, pedido de socorro, arrependimento pelo pecado, promessas, louvação. Também o gênero poético sapiencial trata de temas de todos os tempos e de todos os povos, assuntos da experiência humana universal: amor e ódio, aliança e traição, dúvida e esperança, dominação e rebeldia. No caso da Bíblia, a poesia sapiencial traz à tona algumas questões bem particulares. Em tempos de domínio político, de crise da nação, quando se produz para pagar tributos, que sentido a vida tem? É o que questiona o Cohélet bíblico. Que fazer de uma religião que já não dá conta de promover o encontro com Deus? pergunta o autor de Jó. Ainda assim, haverá tempo para cantar o amor, em tempos de crise - garante o autor de Cântico dos Cânticos.

Se, do ponto de vista da tradução do sentido, as orações e os escritos sapienciais podem não representar um grande desafio, o mesmo não se pode dizer em relação ao estilo, à forma. Na poesia bíblica, uma das formas mais comuns se estrutura como parallelismus membrorum, uma espécie de repetição do verso com outras palavras, mas em estreita correlação com o anterior. Outra forma muito frequente se organiza em versos concêntricos, onde o primeiro se relaciona tematicamente com o último, o segundo com o penúltimo, e assim por diante. De modo geral, as formas poéticas usuais do mundo da Bíblia não são encontradas na nossa poesia popular, com exceção talvez da poesia alfabética e dos ditos proverbiais.

Frente à distância cultural que, em alguma medida, indicava ser inócuo e sem sentido o esforço de traduzir a poesia bíblica na sua forma original, a equipe optou por apresentá-la em nossas formas tipicamente populares: a quadra e o cordel. A opção representou um desafio, particularmente pela grande demanda de tempo implicada na tarefa. Não foram muitos os textos bíblicos traduzidos nessa forma, mas cada um deles consumiu horas e horas de trabalho, em busca da métrica, do melhor sinônimo, da melhor rima.

Na tradução de salmos alfabéticos, além de buscar a palavra, iniciada por tal ou tal letra do alfabeto, que melhor traduzisse o sentido e a sequência dos versos bíblicos, os tradutores precisaram usar, com frequência, o recurso das frases com ordem indireta: adjetivo antes do substantivo, predicado antes do sujeito.

Em relação a textos bíblicos de Eclesiastes, Jó e Cântico dos Cânticos, a equipe adotou a forma da quadra (estrofe de 4 versos) e a do octástico (estrofe de 8 versos). Nesse ponto, distanciou-se um pouco do que se encontra com mais frequência na literatura de cordel que, no mais das vezes, constrói seus poemas com sextilhas (estrofes de 6 versos). O debate entre Jó e seus amigos teólogos lembra, em relação à estrutura do livro, o desafio que ocorre entre repentistas da literatura de cordel. 
Em relação à estrutura das estrofes, a equipe procurou, sempre que possível, seguir este padrão: rimas em que o segundo verso rima com o terceiro, o sexto com o sétimo, e o quarto com o oitavo; rimas ricas, evitando as terminações em aumentativo, em diminutivo ou num mesmo tempo verbal; ritmo de métrica demarcado por sílaba tônica; preferência pela ordem direta das frases. Vejamos resultados práticos daquele esforço.

a) Reza do pobre com todas as letras (tradução livre do Salmo 9, alfabético)

Aclamo ao Senhor de todo o coração,

Abro a boca para contar suas maravilhas.

Bendito seja o santo nome do Altíssimo.

Bato palmas de alegria por causa do Senhor.

Correm para trás meus inimigos,

Caem no chão de medo, diante do Senhor.

Direito e justiça o Senhor me faz,

Defende a minha causa no seu tribunal.

Empreita uma guerra contra os países ricos,

Esquece o nome dos que se dizem poderosos.

Fracasso total para meus inimigos!

Fulmina suas cidades - nem fumaça de lembrança!

Grande é o Senhor! Para sempre!

Garante do seu lugar a firmeza da justiça.

Haverá justiça no universo inteiro,

Hemisfério algum vai ficar sem a sentença.

Inclina-se o Senhor e protege o oprimido,

Injustiça contra o inocente ele vai impedir.

Javé-Deus: o nome do Senhor é de confiança!

Jamais o Senhor abandonou quem o procura.

Limpem a garganta! Cantem com alegria!

Ladainhas de louvor pelas suas maravilhas.

Maltratam e matam o irmão?

Maior é Deus que vinga o sangue derramado.

Não esquece o grito dos oprimidos.

Necessito de sua ajuda, meu Deus!

Olhe, Senhor, a miséria em que me deixaram.

Onde estou? À beira da morte! Salve-me! 
Possa ainda falar em público das suas obras,

Palavras de louvor pela sua proteção.

Quem cavouca um buraco cai dentro dele,

Quebra o pé na armadilha que armou.

Resolve o Senhor fazer justiça:

Redes que armam lhes servem de ratoeira!

Safados! Vão todos para o inferno!

Santo é Deus, mas dele se esqueceram!

Tarda o Senhor, mas não falha para o pobre.

Tempos de aflição estão para terminar.

Urgente, Senhor! Levante-se em meu favor! O

Último a falar não seja o opressor.

Vou ver o Senhor varrer esses valentes!

Vantagens vão contar para os vermes da terra.

Xingue os nossos opressores, Senhor!

Xi! Já estão tremendo de medo!

Zomba o Senhor de quem julgar ser o tal.

Zero é o quanto valem esses homens.

(BÍBLIA-GENTE, v. 3, n. 15, 13/04/1980, p. 2).

b) Vaidade das vaidades, tudo é ilusão (Eclesiastes 1,2-11)

Ilusão das ilusões,

É o que diz o Dirigente.

Toda a vida para a gente

É ilusão, é vaidade.

Que proveito tira o homem

Do suor de sua fadiga?

Fica a terra que é antiga;

Sobra alguém pra eternidade?

O sol nasce e se põe,

Volta sempre ao seu lugar.

No outro dia, é só esperar,

Novamente ele desponta.

Sopra o vento para o sul,

Volta e corre para o norte,

Roda e gira - é sua sorte;

Suas voltas são sem conta. 
Todo rio vai pro oceano,

Mas o mar nunca transborda.

Mesmo cheio, até a borda,

$\mathrm{O}$ rio corre para o mar.

Toda coisa se afadiga

Muito mais que eu sei dizer:

Olho farta-se de ver?

E ouvido, de ouvir?

O que foi é o que será:

O que hoje faz alarde

Vem de novo, cedo ou tarde.

Nada é novo na história.

Diz alguém: "É novidade!"

Isso é velho, meu amigo!

Ninguém lembra o que é antigo;

Pro futuro não há memória.

(BÍBLIA-GENTE, v. 3, n. 22, 01/06/1980, p. 2)

c) Pobre tem sabedoria? (Eclesiastes 9,13-16)

Vi também, à luz do dia,

Este exemplo de sabença

Que pra mim, na minha crença,

Muito grande eu achei:

Certa vez, uma cidade

Bem pequena foi cercada

Por trincheira e paliçada

Pelas tropas de outro rei.

Tinha lá um pobre homem

De saber, capacidade,

Que salvou toda a cidade,

Mas por todos é esquecido.

Digo então: sabedoria

Vale mais que a força nobre;

Mas sabença que é do pobre

Ninguém liga em dar ouvido.

(BÍBLIA-GENTE, v. 3, n. 23, 08/06/1980, p. 1-2. CANTARELA, 1982, p. 6).

d) Discurso teológico de um amigo chato (Jó 5,1-27)

Chama e vê se algum santo

Dá resposta a teu exame.

Louco morre de vexame 
E o tolo de inveja.

O malvado enraíza.

Disse eu: casa maldita!

Filhos morrem ao pé da dita,

Ninguém liga: Assim seja!

A colheita do insensato

O mendigo é que devora;

Pela cerca a leva embora.

E os ladrões vão lá roubar.

Pois o mal não sai do pó,

Nem da terra o sofrimento;

Vêm do homem, num momento,

São faíscas pelo ar.

Rogarei por isso a Deus,

Pedirei ao meu Senhor.

Ele fez com esplendor

Maravilhas sem medida.

Manda a chuva sobre a terra,

Sobre os campos joga a água;

Dos humildes tira a mágoa,

$\mathrm{E}$ aos de luto mostra a vida.

Deus amarra as mãos dos maus

Cujos planos não são retos.

Vai danar com os projetos

Do astuto e sua manha.

É de dia e encontram trevas,

Para andar apalpam o muro,

É de dia e tudo escuro,

Dia é noite! - Que barganha!

Salva o fraco da espada

Do malvado, de sua língua.

Deixará morrer à míngua

A pobreza na mão forte?

Esperança do infeliz!

Tapa a boca da mentira.

Bem feliz de quem com ira

Deus corrige - isto é sorte!

Se ele fere, também cuida;

A mão cura, se ele bate.

Seis angústias Deus combate;

Sete vezes, o mal termina. 
Da miséria Deus te livra,

A espada não te fura,

Das más línguas te segura!

Terás medo da ruína?

Seca e fome não te assustam,

Nem das feras o rugido.

Com as pedras estás unido,

E com os bichos tudo em paz.

Em morada que é tua

Ninguém quer saber de guerra;

Andarás na tua terra,

E do bom tudo terás.

Os teus filhos, multidão!

Que nem mato, os descendentes!

Trigo bom, boas sementes,

Vais maduro ao sepulcro.

Eis o que andei olhando.

Terás fonte mais sabida?

Aprender lição da vida

E tirar daí um lucro.

(BÍBLIA-GENTE, v.3, n. 20, 18/05/1980, p. 2)

e) Resposta de Jó: uma teologia rasurada (Jó 16, 2-5)

Já ouvi diversas vezes

Falação igual a essa.

Mas falar sem que alguém peça

É consolo que não calha.

Quando é que vai ter fim

Atirar discurso ao ar:

Donde tiram pra falar

Tais palavras, que são palha?

Eu também falava assim

Se estivessem em meu lugar.

Também eu sei enxugar

Com presteza o choro alheio.

Arranjava mil palavras

De consolo e de coragem

Do jeitinho que ora fazem.

De vocês eu já estou cheio!

(BÍBLIA-GENTE, v. 3, n. 21, 25/05/1980, p. 1-2) 
f) De palmeiras e pomares: a linguagem do amor (Cântico dos Cânticos 7,7-14)

Como és bela e graciosa,

Delícia minha! Eu te acho

Como o tronco da palmeira

E teus seios são o cacho.

Vou subir, pensei comigo,

Colher o fruto da palma.

Teus seios, cachos de uva,

Fazem bem à minha alma.

Tua boca é maçã cheirosa,

Teus beijos, vinho gostoso

Que de noite molha os lábios

Do bem amado esposo.

Eu gosto do meu amado,

Também ele me quer bem.

Vem comigo aos pomares,

Vem comigo ao campo, vem!

Acordar de manhã cedo,

Ver se a vinha já deu flor,

Se brotou a romãzeira...

Dou-te ali o meu amor.

As mandrágoras cheirando;

Fruta boa aqui tem:

Frutas frescas e maduras

Que guardei para o meu bem.

(BÍBLIA-GENTE, v. 3, n. 19, 11/05/1980, p. 2)

\section{Conclusão}

Inúmeras outras questões e possibilidades relativas à tradução popular da Bíblia poderiam, certamente, ser incluídas no debate. Na esteira do que aqui foi proposto, reitera-se um princípio fundamental, de viés teológico: se na leitura da Bíblia podemos ouvir a palavra de Deus, torna-se exigência fundamental que o texto bíblico seja compreendido pelo leitor atual. 
Concorre para isso, entre outros fatores, uma boa tradução da Bíblia. E ainda: considerando a enorme dificuldade que as pessoas mais simples, em geral, têm para ler, julgamos que a tradução da Bíblia numa linguagem mais popular será sempre bem recebida. Tal exigência permitiria inverter o velho provérbio e afirmar: voz de Deus é voz do povo. Se Deus fala, sua voz não será ouvida e compreendida senão na língua que o povo conhece e fala.

Retomamos também, por sua relevância, outro aspecto teológico-pastoral, afeito à leitura da Bíblia no meio popular: sua leitura comunitária. Sempre valorizando os cursos bíblicos e o trabalho da tradução popular, apostamos igualmente na leitura comunitária da Bíblia. A partir das vivências dos participantes, a leitura comunitária ajudará a superar impasses e limites que se podem encontrar na recepção do texto bíblico.

Subordinado a esses dois princípios teológicos fundantes - a recepção da Bíblia como palavra de Deus e sua leitura comunitária - coloca-se a importante tarefa da tradução. Seu escopo específico, como apontamos anteriormente, gira em torno de um duplo desafio: traduzir o sentido do texto original numa perspectiva de equivalência entre a estrutura semântica profunda originária e a estrutura da língua para a qual se traduz; e realizar isto dando atenção também às características formais, de estilo, do texto original.

Em relação ao conjunto de seu trabalho de assessoria bíblica e tradução de textos bíblicos para a linguagem popular, a equipe do Centro Bíblico de Belo Horizonte avaliou positivamente o alcance de suas atividades. Entretanto, como diz o velho ditado hoje pouco usado, "elogio em boca própria é vitupério". Assim, para encerar este texto, convém ainda destacar aspectos problemáticos da tradução popular da Bíblia.

Um dos grandes problemas da tradução da Bíblia em linguagem popular correlaciona-se à possível desconfiança dos leitores em relação ao texto bíblico apresentado em linguagem excessivamente familiar e cotidiana. Mesmo sabendo que há diferentes traduções da Bíblia, o leitor comum poderá julgar que a presença de palavras e expressões corriqueiras desrespeita o texto bíblico e ameaça sua sacralidade, sua santidade. Assim, um dos grandes desafios que aquela equipe de assessores colocou para si foi na direção de evitar uma tradução popular que criasse problemas em lugar de favorecer a leitura da Bíblia.

Outro aspecto a destacar, nesta conclusão, refere-se à provisoriedade da tradução popular. As línguas bíblicas são línguas antigas, de culturas e contextos diferentes dos nossos, que exigem instrumentos para sua interpretação e atualização. O hebraico bíblico - clássico, lashon hakodesh, a Palavra Sagrada, como dizem os judeus - situa-se a razoável distância 
mesmo do moderno ivrit, falado atualmente em Israel. Da mesma forma, o grego bíblico não se confunde com o idioma romaico, falado hoje em dia na Grécia. As línguas modernas, por seu turno, são dinâmicas: ao mesmo tempo que trazem em seu léxico vocábulos de centenas de anos, incorporam a todo o tempo neologismos, novos significados, novas formas de expressar as experiências dos tempos atuais. Certas palavras, como as gírias, chegam a ter uso meteórico. Assim, frente ao dinamismo das línguas faladas na atualidade, não há como pensar uma tradução popular da Bíblia que não seja provisória.

Por fim, uma questão de extrema complexidade: a distância cultural entre o imaginário bíblico e os tempos atuais se mostra quase que instransponível quando se compara a linguagem da Bíblia com a linguagem da era da internet. Encontramo-nos envolvidos por novos paradigmas, enredados por novas visões de mundo que mudam de forma rápida. Novas hermenêuticas se impõem e questionam a leitura da Bíblia que construímos em passado recente. Gostem ou não os apreciadores do livro físico, também a Bíblia encontrou lugar na internet. Entretanto, a mudança da base material, do livro para a tecnologia digital, não é suficiente para tornar a Bíblia um livro compreensível para o leitor atual. Ficam as perguntas: Como traduzir a linguagem bíblica para a linguagem da era da internet? Que valor sacramental se pode ainda atribuir à Bíblia enquanto "livro" sagrado, quando muitas vezes já se lê o texto bíblico num smartphone, inclusive no âmbito da liturgia?

\section{Referências}

ANTONIAZZI, A. O povo e as traduções da Bíblia: primeiro resultado de uma pesquisa. Vida Pastoral, São Paulo, v. 23, n. 104, p. 15-23, maio/jun. 1982.

ARTOLA, A. M. A Bíblia, Palavra de Deus. In: ARTOLA, A. M.; SÁNCHEZ CARO, J. M. A Bíblia e a palavra de Deus. 2.ed. São Paulo: Ave-Maria, 2005. p. 21-51.

BÍBLIA-GENTE [BíBLIA - Deus caminhando com a - GENTE], São Paulo: Paulinas, 1978-1983.

CANTARelA, A. G. Parábolas, uma pulga atrás da orelha. São Paulo: Paulinas, 1982.

GRUEN, W.; CANTARELA, A.G. A história de José. São Paulo: Paulinas, 1980.

GRUEN, W.; CANTARELA, A. G. Carta aberta de Tiago. São Paulo: Paulinas, 1981.

LADMIRAL, J.-R. A tradução na instituição pedagógica. In: LADMIRAL, J.-R. (org.). A tradução e seus problemas. Lisboa: Edições 70, 1980. p. 16-66.

NIDA, E. A.; TABER, C. R. La traduccion: teoria y practica. Madrid: Cristiandad, 1986. 
OXTOBY, W. G. “Falando em suas próprias línguas": traduções antigas e modernas da Bíblia como expressões da identidade étnica e cultural. Concilium, Petrópolis, v. 257, n. 1, p. 33-46, 1995.

TABER, C. R. Traduzir o sentido, traduzir o estilo. In: LADMIRAL, Jean-René (org.). A tradução e seus problemas. Lisboa: Edições 70, 1980. p. 88- 101.

WOLFF, H. W. Antropologia do Antigo Testamento. São Paulo: Loyola, 1975.

Artigo submetido em 18.12.2019 e aprovado em 26.03.2020.

Antônio Geraldo Cantarela é Doutor em Letras (Literaturas), pela Pontifícia Universidade Católica de Minas Gerais (PUC-MG, 2010). Professor do Programa de Pós-Graduação em Ciências da Religião, da PUC Minas e professor de Filosofia da Linguagem no Instituto Santo Tomás de Aquino. Orcid.org/0000-0003-0579-8886. E-mail: antonio.cantarela@gmail.com

Endereço: R. Dom José Gaspar, 26 / Ap. 102

Coração Eucarístico

30.535-610 - Belo Horizonte - MG 